\title{
CORAK SOSIALISME PESANTREN
}

\section{Husnul Amin}

Sekolah Tinggi Ilmu Tarbiyah (STIT) Raudhatul Ulum Kota Palembang

Jl. Raya Lintas Timur Sakatiga Indralaya Ogan Ilir Sumatera Selatan 30662

Email: Amin_husnul@yahoo.com

\begin{abstract}
ABSTRAK
Fokus tulisan ini menggambarkan secara dialogis ragam ideologi yang melingkupi pesantren. Pendekatan yang digunakan adalah filsafat pendidikan Islam. Sejumlah ideologi yang diduga mempengaruhi pesantren dielaborasi oleh teori ideologi pendidikan dari O'neil (2002) kemudian dikritisi berdasarkan filsafat (pendidikan) Islam. Hasil penyelidikan menunjukkan bahwa beragamnya jenis pesantren mengandaikan adanya keragaman ideologi yang dianutnya. Ia bisa berideologi konservatif, liberal bahkan sosialis (religius). Telaah liberasionisme O'neil dapat mengungkap aspek kemasyarakatan pesantren tetapi ia tidak (mungkin) menyebut sebagai sosialisme. Telaah yang lebih objektif dapat menunjukkan bahwa pesantren mengandung sejumlah nilai yang berideologi sosial, yakni saat pesantren; 1) berprinsip bahwa santri harus diperlakukan secara kolektif; 2) berpegang teguh pada prinsip kesatupaduan antara pesantren dengan masyarakat; 3) dilandasi ajaran teologis yang menuntut kebermanfaatan bagi masyarakat; 4) bertujuan membentuk perilaku sosial santri yang lebih maju; 5) santri belajar secara terus-menerus (mondok); 6) mengembangkan metode halaqah yang berpotensi mengajarkan kebersamaan (sosialis).
\end{abstract}

Kata Kunci: Ideologi, Sosialisme, Liberalisme, Pesantren

\section{ABSTRACT}

This writing is to elaborate the idea of reconstructing system of Pesantren. This is due to the demand of real social needs and competition on the quality among educational institutions. As a result, reconstructing education system of Pesantren is a must in order to prepare Pesantren to be modern educational Institutions that are ready to compete with other educational institutions. Therefore, Pesantren needs one comprehensive education system that makes it function as a transmission either in form of formal or non-formal education. As the impact, Pesantren can actualize the essence of human life that is always involved in various changes in times since the dynamics of Pesantren in the future cannot be separated from the process of globalization. In this case, the existence of both traditional and modern Pesantren in the future will be determined by its ability to integrate culturally with the international system characterized by a more rational, dynamic and competitive relationship system.

Keywords: Updates, System of Education, Pesantren 


\section{PENDAHULUAN}

Nilai dasar pesantren bersumber dari ajaran Islam, namun terdapat perbedaan filosofis dalam memahami dan menerapkan ajaran Islam tersebut sehingga dapat menjadi sebuah sistem pendidikan model pesantren. Perbedaan tersebut lebih dikarenakan beragamnya kondisi sosial budaya masyarakat dan pelaku pesantren itu sendiri. Pelaku utama pesantren adalah kiai. Perbedaan pandangan hidup kiai sebagai pengasuh/pemimpin pesantren menyebabkan pemahaman/ideologi dan teologi yang dianut oleh pesantren pun berbeda-beda. Di sini, pada dasarnya, semua pesantren mempunyai ciri khas tersendiri.

Ideologi kiai yang berbeda-beda itu bercampur dengan struktur, konteks dan realitas sosial yang juga berbeda-beda. Hasil perpaduan keduanya membentuk dan menetapkan tujuan serta pilihan cara yang akan ditempuh oleh pesantren dalam rangka mewujudkan tujuan tersebut. Dengan begitu, pandangan hidup pesantren pun bisa berubah dan berkembang sesuai dengan tuntutan dan perkembangan realitas sosial yang terjadi pada dan dilakoni oleh kiai. Sistem nilai pesantren yang dapat berubah tersebut, prosesnya didasarkan atas dialog yang terus menerus antara kepercayaan terhadap ajaran dasar agama Islam yang diyakini oleh kiai dengan realitas sosial. Dalam Islam, pemahaman terhadap ajaran dasar agama yang berpusat pada tauhid atau ke-Esaan Tuhan disebut dengan hablum min Allah sedangkan ajaran yang memuliakan kehidupan sosial disebut dengan hablum min an-nas (Mastuhu, 1994: 26).

Pada mulanya pondok pesantren hanya mengajarkan ilmu agama. Buku yang dipelajari disebut kitab kuning (al-kitâb at-turâts), seperti; kitab Riyâdhus Shâlihîn, Bulûghul Marâm, Tafsir Âyâtul Abkâm. Kitab-kitab tersebut diajarkan sesuai dengan kemampuan baik psikologis maupun kognitif santri. Metode pembelajaran yang digunakan adalah metode bandongan (menyimak) dan sorogan (meniru/mengulang). Cara mengajar seperti ini pada awalnya diyakini sebagai satu-satunya 'sistem' pembelajaran terbaik pesantren dan beberapa pesantren hingga kini masih menjalankannya. Seiring dengan perkembangan zaman (tuntutan masyarakat), pada satu dekade terakhir ini, banyak pula pesantren yang telah mengadopsi sistem pembelajaran madrasah dan/atau sistem pembelajaran sekolahan (diskusi, praktikum dan eksperimen). Hal ini disebabkan, banyaknya pesantren yang telah membuka dan memiliki madrasah bahkan sekolah berbasis Islam (sekolah Islam terpadu). Meskipun sejumlah pesantren kini memiliki sejumlah materi baru namun materi lama (kitab kuning/turâts) tetap diberikan kepada siswa/santri. Hal ini dimaksudkan, agar lulusannya dapat melanjutkan studinya ke jenjang pendidikan yang lebih tinggi, termasuk ke perguruan tinggi umum (Raharjo, 1985: 273). Berarti kini, pesantren sudah tidak persis sama dengan pesantren pada abad ke-18. Ada sejumlah ideologi baru yang masuk ke pesantren (modernisme, liberalisme dan sosialisme) yang sepanjang perjalanan eksistensinya terus berdialog dengan ideologi asli pesantren (idealisme religius, komunalisme dan sosialisme religius). 
Proses dialogis antar ideologi yang melintas dalam sejarah perkembangan pesantren inilah yang menjadi fokus tulisan ini. Sejumlah fakta historis pesantren yang sepanjang zaman berupaya menyesuaikan, berdialog bahkan 'diserang/ digempur' oleh karakteristik dan perkembangan zamannya mengandaikan adanya sejumlah muatan ideologis yang di satu sisi, satu sama lain saling mengisi dan mengasimilasi namun di sisi lain dapat saling mengeliminasi. Adanya aktivitas saling mengisi, mengasimilasi maupun mengeliminasi tersebut menunjukkan bahwa ada sejumlah muatan ideologi yang perlu diteliti. Pendekatan yang digunakan untuk menganalisis persoalan tersebut adalah filsafat pendidikan Islam. Sejumlah ideologi yang dimungkinkan melingkupi dan mempengaruhi pesantren dielaborasi berdasarkan teori-teori ideologi/politik pendidikan dari O'neil kemudian sedemikian rupa dikritisi berdasarkan filsafat (pendidikan) Islam.

\section{PEMBAHASAN}

Ada kecenderungan bahwa pesantren sedang berupaya menyesuaikan dengan sistem pendidikan madrasah dan sekolah umum. Hal ini mendorong sebagian ahli pendidikan Islam mengklasifikasikan pesantren ke dalam beberapa kategori, yaitu;

1. Pondok pesantren yang di dalamnya hanya terdapat masjid dan rumah kiai. Di sini, kiai menggunakan rumahnya sebagai tempat bagi santri untuk mempelajari kitab/ilmu agama Islam. Metode yang digunakan lebih banyak menggunakan metode hafalan, tuntunan atau bandongan. Caranya, kiai membacakan, menerjemahkan dan menjelaskan maksud kitab/buku kepada santri. Santri menyimak halhal yang disampaikan kiai sambil mencatat arti dan maksud kitab tersebut. Metode lain yang dikenal di pesantren yaitu metode sorogan. Teknik pembelajarannya, kiai membacakan suatu kitab lalu santri menyimak dan langsung menirukan dengan membacakan kitabnya di hadapan kiai. Kiai kemudian menyimak dan mengoreksi bacaan santrinya kemudian menambah/melanjutkan bahan ajar baru untuk santri tersebut.

2. Pondok pesantren yang memiliki fasilitas masjid, rumah kiai dan asrama tempat tinggal santri. Pesantren jenis ini menyelenggarakan pengajian kitab kuning/klasik yang berisi sejumlah ilmu agama Islam dengan menggunakan metode hafalan, tuntunan dan resitasi.

3. Pondok pesantren yang memiliki fasilitas sama dengan nomor dua dan ia pun menyelenggarakan pendidikan formal/madrasah. Dengan demikian, sistem pondok dan sistem persekolahan berjalan saling melengkapi di antara keduanya.

4. Pondok pesantren yang telah memiliki karakteristik pondok pesantren nomor tiga dan menyelenggarakan/mengembangkan pendidikan 
keterampilan seperti peternakan, kerajinan rakyat, koperasi, sawah dan ladang.

5. Pondok pesantren pada level ini dianggap sebagai pesantren yang telah berkembang dan maju. Tipe/kategori nomor lima ini disebut pondok pesantren modern. Pondok pesantren ini di samping telah memiliki komponen fisik dan penyelenggaraan pendidikan seperti pondok pesantren nomor empat, juga memiliki perpustakaan, dapur umum, ruang tamu, ruang makan, kantor administrasi, toko dan koperasi, gedung pertemuan, kamar mandi, WC dan labolatorium yang memadai. Aktivitas pendidikan pesantren kategori ini adalah menyelenggarakan; pengajian kitab klasik/kuning, pembelajaran sejumlah materi yang lazim diberikan di madrasah dan/atau sekolah umum dari tingkat dasar hingga pendidikan tinggi, ditambah dengan materi-materi pendidikan vokasional/keterampilan dan program pengembangan lingkungan.

(Saridjo, 1979: 9-10).

Beragamnya jenis dan kategori pesantren mengandaikan adanya keragaman nilai, budaya dan ideologi yang dianut oleh pesantren. Berarti, suatu studi khusus yang berorientasi pada penelusuran sejumlah nilai dan ideologi pesantren diperlukan, agar pembahasan teoretisnya, tidak menjadi ahistoris. Teori dasar yang digunakan untuk menelaah ideologi pesantren ini adalah teori ideologi pendidikan dari O'neil. Ia memetakan ideologi pendidikan menjadi dua kelompok besar yaitu konservatif (fundamentalisme, intelektualisme) dan liberal (liberasionisme dan anarkisme) (O'neil, 2002: x1 dan Muthohar, 1994: 43).

Konservatisme ditandai dengan adanya sikap dari seseorang/sekelompok orang yang cenderung kolot, senang mempertahankan keadaan, kebiasaan dan tradisi. Konservatisme ingin mempertahankan tradisi, stabilitas sosial dan pranata yang ada. Jika berkembang ia menghendaki perkembangan yang setapak demi setapak. Ia menentang perubahan radikal (Ali, 1994: 290 dan 520).

Ideologi pendidikan konservatif lebih mengutamakan terpeliharanya nilai lama yang sudah menjadi tradisi dan sudah teruji oleh waktu. Perubahan sosial merupakan hal yang tidak harus diperjuangkan karena merupakan ketentuan sejarah, bahkan berbenturan dengan takdir Tuhan. Pendidikan sebagai proses pemberdayaan manusia dimaknai sebagai usaha manusia yang keberhasilannya sepenuhnya ada di tangan Tuhan (konservatisme religius). Mereka menerima beberapa perubahan sosial, tetapi tetap berpegang pada nilai-nilai tradisi lama yang masih relevan dengan tatanan sosial. Mereka menginginkan perubahan tidak secara radikal tetapi bertahap sesuai dengan perkembangan masyarakat. Tujuan utama pendidikan konservatif melestarikan dan menyalurkan pola perilaku sosial konvensional. Sekolah didirikan untuk mendorong, memahami dan menghargai lembaga, tradisi dan 
proses budaya yang telah teruji oleh waktu (konservatisme sosial) (O'neil, 2002: 297 dan Muthohar, 2007: 44 dan 45).

Rasa hormat terhadap hukum diperlukan agar tatanan sosial tetap terjaga. Siswa memerlukan bimbingan ketat dan pengarahan yang jelas sebelum ia terbelajarkan secara efektif. Anak, secara moral memperoleh kesempatan, namun keberhasilan, ditentukan oleh prestasi dan kebaikan personal. Secara personal, Siswa bebas menentukan nasibnya sendiri. Wewenang pendidikan diserahkan pada pendidik profesional yang matang, bertanggung jawab, menghargai proses, bijaksana dalam menghindari perubahan yang berlebihan dan peran guru didasarkan pada status sosial yang dimilikinya. Kurikulum sekolah diarahkan untuk membantu siswa agar mencapai pemenuhan nilai budaya konvensional. Penekanannya terletak pada penguasaan keterampilan dasar, pengetahuan praktis dan pelatihan watak. Materi pelajaran diorientasikan pada hal yang bersifat akademik daripada praktis dan intelektual. Misi pendidikan konservatisme adalah mengembangkan ketaatan terhadap lembaga dan budaya yang telah teruji oleh waktu disertai dengan rasa hormat yang mendalam terhadap hukum dan tatanan sebagai landasan setiap jenis perubahan sosial yang konstruktif (Muthohar, 2007: 44 dan 45).

Dua ideologi yang termasuk pada konservatif adalah fundamentalisme dan intelektualisme. Fundamentalisme berasal dari kata fundamen (dasar, asas dan hakikat) yang berkembang menjadi fundamental (sifat), fundamentalis (pelaku) dan fundamentalisme (paham). Fundament sebagai paham, cenderung memperjuangkan sesuatu secara radikal dan alisme diartikan sebagai gerakan yang bersifat kolot, reaksioner dan selalu merasa perlu kembali ke ajaran agama yang asli seperti yang tersurat dalam kitab suci (Ali, 1994: 281). Kehidupan yang baik terwujud dalam ketaatan terhadap wahyu. Fundamentalisme pendidikan mengajarkan kebenaran pengetahuan intuitif, iman dan wahyu. Kurikulum yang dijalankan berpola; 1) melatih siswa menjadi pribadi yang baik berdasarkan moral tradisional; 2) membangun budaya lama dan membantu siswa menemukan kembali nilai-nilai yang terkandung dalam tradisi; 3) meregenerasi keyakinan dan moral masyarakat sesuai dengan tradisi yang berlaku; 4) mengarahkan menguasai jenis keterampilan akademik praktis yang diperlukan siswa agar kelak menjadi anggota aktif dalam masyarakat. Metodologi pembelajaran fundamentalisme menekankan pada metode pembelajaran tradisional (hafalan, ceramah, belajar dan diskusi kelompok yang terstruktur, ketat, diawasi dan selalu terbimbing). Pembelajaran ditentukan dan diarahkan oleh guru yang dianggap mempunyai kesempurnaan moral dan akademik. Siswa tidak mempunyai pencerahan intelektual sendiri. Evaluasi bertujuan mengukur kognisi, informasi, kebiasaan dan keterampilan yang dimiliki siswa (Muthohar, 2007: 45-48).

Intelektualisme berasal dari kata intelek yang berarti 'daya akal budi' dan kecerdasan berpikir (Ali, 1994: 252). Intelektualisme pendidikan memandang bahwa nalar adalah syarat yang diperlukan untuk memahami kebenaran ilmu. Tujuan pendidikan intelektualisme yaitu mengetahui, merumuskan, melestarikan 
dan menyalurkan kebenaran. Sekolah diarahkan untuk mengajar siswa menalar dan menyalurkan kebijaksanaan masa silam. Otoritas pendidikan harus dikendalikan elit intelektual yang berpendidikan tinggi. Wewenang guru didasarkan kepada kebijaksanaan (wisdom) sang guru yang lebih tinggi dibanding dengan siswa. Kurikulum menekankan pada bagaimana melatih siswa agar mampu bernalar secara jelas dan tertata yang bisa dipraktikan secara luas. Pembelajaran dilaksanakan secara tradisional, [ceramah, hafalan, tes-tes sokratis (diarahkan oleh guru) dan diskusi kelompok terstruktur]. Tes lebih bercorak esai dan pilihan obyektif dengan menekankan pada kognitif individu (Muthohar, 2007: 51).

Antitesis dari ideologi konservatisme adalah liberalisme. Liberalisme berpandangan bebas (luas dan terbuka) (Ali, 1994: 591). Liberalisme pendidikan bertujuan melestarikan dan meningkatkan mutu tatanan sosial yang ada dengan mengajarkan anak sejumlah cara menghadapi masalah kehidupannya sendiri secara efektif (O'neil, 2001: 412). Kaum liberalis menganggap bahwa sekolah merupakan sebuah lembaga pendidikan yang berupaya menyediakan informasi dan keterampilan yang diperlukan siswa. Siswa belajar dan diajar secara efektif cara memecahkan persoalan praktis secara ilmiah. Tujuan pendidikan adalah mempromosikan perilaku personal yang efektif. Hal ini didasarkan pada anggapan bahwa; 1) pengetahuan merupakan alat dalam pemecahan masalah praktis; 2) pemikiran efektif adalah kecerdasan praktis; 3) ada kemanunggalan pribadi; 4) ada perkembangan personal yang efektif; 5) cara memecahkan masalah didasarkan pada kebutuhan individual yang ada; 6) perubahan sosial secara tidak langsung merupakan perubahan berskala kecil yang terus-menerus; 7) sistem penyelidikan eksperimental terbuka itu efektif, ilmiah dan rasional dan 8) wewenang intelektual tertinggi terletak pada pengetahuan yang diperoleh dari pembuktian eksperimenal (Illich, 1982: 30). Kurikulum sekolah harus menekankan pada; 1) keefektifan personal, untuk melatih anak menyesuaikan diri dengan tuntutan dan situasi yang berkembang; 2) pemecahan masalah secara praktis; 3) program/pelajaran harus ditentukan lebih dahulu; 4) hal yang bersifat intelekual praktis daripada akademis; dan 5) penjelajahan terbuka dan kritis terhadap masalah dan isu kontemporer. Guru harus menggunakan tata cara pemecahan masalah berdasarkan minat siswa. Disiplin dan hafalan bisa bernilai jika ia diperlukan demi menguasai suatu keterampilan untuk menangani masalah personal secara efektif. Kegiatan belajar mengajar kolaboratif antara guru dan siswa, lebih baik daripada ditentukan dan diarahkan oleh guru (Muthohar, 2007: $60)$.

Dua ideologi yang termasuk ideologi pendidikan liberal adalah liberasionisme dan anarkisme (O'neil, 2001: 466). Liberasionisme pendidikan adalah paham yang beranggapan bahwa sasaran pendidikan adalah penanaman pembangunan kembali masyarakat mengikuti alur berkemanusiaan (humanistik) yang menekankan pengembangan potensi individu sebagai manusia. Ideologi ini bertujuan mendorong pembaruan sosial. Hal ini dilakukan dengan mamaksimalkan kemerdekaan personal dan membela kondisi-kondisi yang 
manusiawi di masyarakat. Metode yang diterapkan harus balance atau seimbang antara pemahaman dan pemecahan masalah. Ujian didasarkan pada perilaku para siswa yang tanpa dilatih atau dipersiapkan lebih dulu. Guru harus bersifat demokratis dan obyektif dalam menentukan tolok ukur perilaku. Tolok ukur ini harus ditentukan bersama dengan siswa, sebagai cara mengembangkan rasa tanggung jawab moral mereka (Muthohar, 2007: 64-65 dan O'neil, 2001: 466-477).

Anarkisme pendidikan berasal dari kata dasar 'anarki' yang berarti tidak ada pemerintah, undang-undang, peraturan dan ketertiban. Anarkisme adalah ajaran yang menentang setiap kekuatan Negara seperti pemerintahan dan undang-undang (Ali, 1994: 38). Dalam konteks pendidikan, anarkisme merupakan paham yang beranggapan bahwa pendidikan merupakan proses yang tidak terlembaga dan tidak mengekang. Belajar merupakan hak masing-masing individu. Pola dan tata cara belajar bergantung pada masing-masing individu. Tujuannya, individu mampu merombak secara cepat tatanan sosial yang ada. Pendidikan diadakan untuk membawa pembaruan atau perombakan berskala besar dan bersifat segera pada masyarakat dengan menghilangkan persekolahan wajib. Implikasinya, sistem sekolah formal yang ada harus dihapuskan dan digantikan dengan pola belajar suka rela dan mengarahkan diri sendiri. Akses bahan pendidikan diperoleh secara bebas dan universal serta kesempatan belajar harus disediakan dan tanpa sistem pengajaran wajib (Muthohar, 2007: 64-65 dan O'neil, 2001: 482-492).

\section{Sosialisme Liberal Pesantren}

Ideologi pesantren bersumber dari ajaran Islam. Karena itu di pesantren, tidak akan ditemui ideologi konservatif, liberal dan anarkis, tetapi mungkin saja dalam unsur-unsur tertentu, secara sistemis, pesantren menganut (berdimensi) paham konservatif, liberal atau anarkis (Muthohar, 2007: 93).

Secara sistemis, unsur organik pesantren terdiri atas kiai, ustadz, santri dan pengurus. Unsur anorganik pesantren terdiri atas tujuan, nilai, pendekatan, fungsi, prinsip dan kurikulum pendidikan pesantren. Kiai adalah tokoh kharismatik yang diyakini memiliki pengetahuan agama yang luas sebagai pemimpin sekaligus pemilik pondok pesantren. Gelar kiai diberikan kepada seseorang yang menguasai ilmu di bidang agama Islam (Ghazali, 1996: 21). Keberadaan kiai dalam pesantren sangat sentral. Kiai berfungsi sebagai penggerak dalam mengemban dan mengembangkan pesantren. Karena itu, kiai dan pesantren bagaikan dua sisi dari mata uang yang sama dan mereka selalu berjalan bersama. Jika posisi kiai dalam pesantren terlalu dominan dan menjadi sumber rujukan satu-satunya dari pesantren tersebut (individual interprise), maka pesantren tersebut masuk dalam kategori konservatif (Muthohar, 2007: 105). Mastuhu (1994) mengatakan ada beberapa tipologi kepemimpinan kiai, yaitu; 1) kepemimpinan tunggal dengan tetap meminta pertimbangan para pembantu kiai (contoh; Pesantren Sukorejo, Blok Agung dan Paciran); 2) kepemimpinan kolektif (Pesantren Guluk-guluk, Tebu Ireng dan Yayasan Pondok Pesantren Gontor). 
Kepemimpinan kolektif dan yayasan menempatkan kiai sebagai koordinator. Dengan kepemimpinan yang memungkinkan pengambilan keputusan secara bersama karena terdiri dari banyak pimpinan dalam pesantren, maka kepemimpinan kiai tipe ini, masuk ke dalam kategori berideologi liberalisme. Mereka tidak menerapkan paham wewenang intelektual tertinggi terletak pada mereka yang secara akurat memahami konsekuensi dari keburukan kapitalisme. Kepemimpinan kolektif pesantren dianggap telah menerapkan pola kepemimpinan demokratis-partisipatoris (Muthohar, 2007: 105-106).

Di pesantren, guru menempati peran strategis karena ia selain bertindak sebagai penjaga moral setelah kiai, juga dituntut secara intelektual, terampil dalam mendidik siswa. Guru tidak hanya berfungsi sebagai pengajar di kelas saja, melainkan harus mampu menciptakan suasana pergaulan yang edukatif di luar kelas. Guru merupakan fasilitator bagi perserta didik untuk melakukan berbagai kegiatan guna memecahkan masalah (how to think bukan what to think) (Nasution, 2003: 24-25). Kini banyak pesantren yang menyesuaikan kualitas guru dengan Peraturan Pemerintah Nomor 19 Tahun 2005 tentang Standar Nasional Pendidikan terutama dalam Bab VI, Pasal 28, yaitu;

1. Pendidik harus memiliki kualifikasi akademik dan kompetensi sebagai agen pembelajaran, sehat jasmani dan rohani, serta memiliki kemampuan untuk mewujudkan tujuan nasional.

2. Kualifikasi akademik sebagaimana yang dimaksud ayat (1) adalah tingkat pendidikan minimal yang harus dimiliki oleh seorang pendidik yang harus dibuktikan dengan ijazah dan/atau sertifikasi keahlian yang relevan sesuai peraturan perundang-undangan yang berlaku.

3. Kompetensi sebagai agen pembelajaran pada jenjang pendidik dasar dan menengah serta pendidik usia dini.

4. Seorang yang tidak memiliki ijazah/sertifikasi keahlian sebagaimana dimaksud pada ayat (2) tetapi memiliki keahlian khusus yang diakui dan diperlukan dapat diangkat menjadi pendidik setelah melalui uji kelayakan dan kesetaraan (Peraturan Pemerintah RI nomor 19 Tahun 2005 dan Muthohar, 2007: 106).

Santri adalah manusia yang menurut Islam memiliki fitrah. Di pesantren, santri dipandang mempunyai daya kelebihan dan kelemahan yang perlu diperbaiki. Jika santri, terlalu didasarkan pada kesamaan, perbedaan, kelebihan dan kekurangan bawaan, maka pesantren tersebut dikategorikan konservatif. Saat pesantren berprinsip bahwa santri harus diperlakukan secara kolektif, maka ia menjadi sosialis. Di pesantren (modern), santri tidak hanya belajar sesuai kurikulum yang ditentukan baik secara lokal maupun nasional, tetapi juga terlibat dalam berbagai kegiatan ekstrakurikuler (praktik berbahasa Arab dan Inggris, olahraga, kesenian, berpidato dan kegiatan lain yang dikoordinir oleh bagian pendidikan dan pengajaran serta pengurus organisasi santri. Sistem pendidikan pesantren menggunakan pendekatan kesatupaduan antara kegiatan belajarmengajar dengan kehidupan sehari-hari masyarakat. Santri tinggal di (pondok) 
pesantren selama 24 jam sehingga layak disebut dengan full day/boarding scholl. Ketika santri dimaknai sebagai individu yang otonom maka ia dikategorikan liberal. Di pesantren, santri bebas menentukan nasibnya sendiri. Santri pun dituntut mengembangkan kemandirian yang merupakan ciri liberalisme (Muthohar, 2007: 106-107). Berdasarkan penelitian Mastuhu (1994), pengurus pesantren (modern) umumnya dipahami telah mencerminkan ciri-ciri liberalisme dan liberasionisme. Pengurus yang berperan sebagai penjaga moral, mencerminkan nilai-nilai pendidikan konservatif. Adanya, pengurus dalam pesantren menandakan bahwa pesantren tidak berideologi anarkis yang menginginkan kebebasan secara absolut dari santrinya (Muthohar, 2007: 107).

Unsur anorganik pesantren terdiri atas tujuan, nilai, pendekatan, fungsi, prinsip dan kurikulum pendidikan pesantren. Tujuan pesantren, umumnya, berada di tangan kiai dan/atau bersama dengan para pembantunya (badal) yang secara intuitif disesuaikan dengan suasana pesantren. Karena itu, pada dasarnya, semua pesantren merupakan hasil usaha pribadi atau individual (individual enterprise) (Madjid, 1997: 6). Karena itu, pesantren di satu sisi, secara internal bercorak otoritarian namun di sisi lain, secara eksternal liberal. Seiring dengan perkembangan dan tuntutan zaman, sejumlah pesantren sudah ada yang memiliki arah dan tujuan yang jelas untuk kemudian dijadikan acuan dan target yang akan dicapai. Secara ideologis, umumnya pesantren bertujuan membentuk manusia yang memiliki kesadaran tinggi bahwa ajaran Islam merupakan nilainilai yang bersifat menyeluruh. Dalam konteks sosiologis, 'lulusan' pesantren diharapkan memiliki kemampuan tinggi dalam merespons terhadap tantangan dan tuntutan (sistem) hidup sosial yang ada. Mastuhu (1994: 55) merumuskan tujuan pesantren pada dasarnya mewujudkan dan mengembangkan kepribadian Muslim, yaitu kepribadian yang beriman dan bertaqwa kepada Tuhan Yang Maha Esa, berakhlak mulia, bermanfaat bagi masyarakat, berkhidmat kepada masyarakat dan kiai dengan jalan menjadi kawula (mengikuti sunah Nabi), mampu berdiri sendiri, bebas dan teguh dalam kejayaan Islam di tengah masyarakat, mencintai ilmu dan mengembangkan kepribadian Indonesia. Dengan penekanan pada kebermanfaatan bagi masyarakat, pesantren dapat dipandang memiliki ideologi sosialis kerakyatan, yakni berbuat baik kepada orang tua, kerabat, fakir miskin, yatim dan sesama manusia (QS. Al-Baqarah [2]: 83).

Arifin dalam Sumpeno (2002: 12) menjelaskan bahwa tujuan pesantren terbagi dua yaitu mempersiapkan santri untuk memiliki pengetahuan ilmu agama yang mendalam dan membimbing santri untuk menjadi manusia yang berkepribadian Islami guna membimbing masyarakat sekitar melalui ilmu dan amalnya. Dalam konteks ideologi pendidikan kontemporer, secara simultan, tujuan pesantren telah sesuai dengan prinsip-prinsip dasar ideologi pendidikan baik fundamentalisme, intelektualisme, konservatisme, liberalisme, liberasionisme maupun anarkisme (Muthohar, 2007: 95). Namun penekanan pada aspek kemasyarakatan menandai bahwa pesantren berdimensi ideologi liberasionisme. 
Dalam konteks liberasionisme, santri dituntut mampu mengubah masyarakat. Namun, sebelum mengubah masyarakat ia harus bermasyarakat. Ada komunalisme di sini. Inilah ciri sosialis, kepemilikan bersama. Pesantren pada dasarnya didirikan oleh masyarakat (kiai) untuk melayani dan memenuhi kebutuhan masyarakat. Jika dipadukan antara peran kiai yang secara internal otoritarian, sementara secara eksternal liberal dan secara dialektis, sosialis, maka secara keseluruhan, pesantren mencerminkan nilai kebebasan individual yang sosialis.

Ideologi konservatif nampak dari sejumlah tradisi pesantren yang masih tetap dipertahankan dan dikembangkan, antara lain nilai ketuhanan (teosentris), ilmu, kearifan, kesederhanaan dan kolektivitas. Secara umum, pesantren tetap mempertahankan kitab kuning sebagai rujukan. Kitab kuning bagi pesantren adalah khazanah intelektual ulama salaf yang harus dipertahankan. Pesantren juga memandang ulama salaf sebagai pewaris Nabi yang menjadikan dirinya sebagai pembawa misi kebenaran al-Qur'an dan Hadits yang bersumber dari Allah SWT.

Dalam konteks liberalisasi, pesantren adalah salah satu pendidikan Islam yang dinamis dan cenderung berupaya memodernisasi diri, sehingga ia tengah berusaha memasuki "dunia baru". Modal dasar liberalisme pesantren adalah adanya tuntutan kemandirian dari semua santri. Santri harus bisa mengatur keperluan pribadi, kegiatan bersama antar santri atau mengatur aktivitas sosialnya dengan masyarakat. Perilaku-perilaku tersebut mengarah pada pembentukan perilaku sosial yang efektif dan lebih maju (al-mubâfadzatu 'ala al-qadîm as-shalih wa al-akbdžn bi al-jadîd alashlab). Dalam konteks modernisasi, pesantren sering melakukan diversifikasi jenis pendidikan dan menambah dengan kegiatan vocational yang bersifat duniawi (berdagang) dengan tujuan membekali santri setelah lulus dari pesantren. Banyak pesantren, saat ini, yang menyelenggarakan unit pendidikan baru berupa madrasah formal seperti MTs, MA, SMK, STM bahkan Perguruan Tinggi. Di beberapa pesantren saat ini juga menjadi basis pengembangan potensi kelautan (pesantren bahari) dan pertanian (pesantren agrobisnis) (Sumpeno, 2002: 13). Namun, pesantren belum/tidak sejalan dengan ideologi anarkisme yang berupaya menghapuskan sekolah wajib. Bagi pesantren, sekolah, madrasah, pengajian dan sebagainya merupakan institusi pendidikan yang menjadi sarana efektif untuk mewariskan khazanah intelektual keislaman. Menurut Steenbrink, dalam melakukan pembaruan, pesantren bersikap "menolak sambil mencontoh" (Muthohar, 2007: 96). Prinsip kehatian-hatiannya dalam menerima modernisasi masih menjadi ciri khas pesantren.

Zarkasyi (1973: 6) menjelaskan bahwa hakikat pendidikan pesantren terletak pada isi dan jiwanya. Isi pendidikan pondok pesantren terletak pada "pendidikan rohani", yang pada masa lalu telah berhasil melahirkan mubaligh dan pemimpin umat dalam berbagai kehidupan. Pembinaan iman dan amal seperti sholat berjamaah, etika dan sopan santun, ukhuwah (persaudaraan), ta'âwun (tolong menolong atau kooperatif), ittihâd (persatuan), thalabul ilmi 
(menuntut ilmu), ikhlas, jihad (berjuang) dan thâ'at (patuh) merupakan nilai-nilai yang dijaga oleh pesantren. Dalam perkembangannya, pesantren telah mengembangkan isi pendidikannya dengan menambah berbagai komponen kurikuler ke dalam sistem pembelajarannya, seperti kepramukaan, keterampilan, kesenian, kesehatan dan olah raga bela diri. Dengan demikian, nilai yang dikembangkan pesantren tidak hanya berorientasi ukhrawi, tetapi juga duniawi yang satu sama lain mempunyai hubungan vertikal dan hirarkis (Mastuhu, 1994: 281-282).

Dalam konteks ideologi pendidikan, nilai-nilai pesantren mencerminkan ideologi konservatif dan liberal. Pesantren menghendaki manusia menjadii insân kâmil (bertakwa kepada Allah SW'T) dan berbuat baik kepada sesama (al-akblâq al-karimah) serta mampu menjadi pemimpin umat (khalifatullâh fil ardh). Nilai semacam ini dikehendaki paham fundamentalisme yang menghendaki manusia sebagai agen moral dan pewaris moral. Dalam konteks intelektualisme, manusia secara kodrati diciptakan sebagai makhluk yang berakal. Dalam konteks sosialisme, manusia merupakan makhluk sosial yang dengan perantaranya dapat mencapai nilai-nilai ketuhanan yang mapan (konservatisme-sosialis).

Dalam konteks pesantren, seorang santri/manusia berdimensi ketuhanan, kedirian dan keumatan. Pesantren sedemikian rupa berupaya mempersiapkan santrinya untuk berubah menjadi lebih baik, bermanfaat bagi umatnya setelah lulus dan membekali dirinya dengan keterampilan. Di sini, pesantren sepenuhnya mengembangkan secara efektif potensi personal/santri (liberalisme) selain ia juga dianggap sebagai kontruksi sosial dan budaya yang pengejawantahannya berdialektika dengan tuntutan masyarakat (Muthohar, 2007: 98).

Bagi seorang santri, motivasi untuk bermanfaat bagi umat dan orang lain pasca lulus dari pesantren adalah motivasi tertinggi. Hal ini dilandasi doktrin teologi khair an-nâs anfáubum li an-nâs, sebaik-baik manusia adalah yang paling bermanfaat bagi manusia lain. Untuk itu, seorang santri sadar betul, jika untuk bisa berperan secara efektif seperti itu, mereka harus mempersiapkan kepribadiannya baik secara intelektual, moral maupun spiritual. Bagi seorang santri, di pundaknya terpikul tugas untuk memperbaiki umatnya, dalam arti melakukan perubahanperubahan menjadi lebih baik. Saat kehidupan kiai, santri dan masyarakat berdialektika maka ia bercorak liberasionisme-sosialis (socialized psyche). Corak ideologi ini tidak dibahas secara khusus oleh O’neil. Ia hanya menandai sebagai liberasionisme reformis. Akan tetapi ideologi ini tidak seluruhnya bisa mewakili corak pesantren yang kecuali liberal juga sosial (Liberalis-Sosialis) (O'nel, 2002: 469).

Secara umum, filsafat pendidikan memandang manusia secara dualistik. Aspek pribadi dan sosial dipahami secara terpisah. Ideologi pendidikan empirisme Locke (1632-1704), cenderung menempatkan manusia sebagai pribadi. Manusia ibarat kertas kosong (tabularasa) yang bisa diisi oleh apa pun termasuk kehidupan sosial di luar dirinya. Nativisme Schopenhauer cenderung menempatkan manusia sebagai pribadi yang punya potensi/bakat individual. Konvergensi Stern (1871-1939) 
mengupayakan suatu pertemuan yang juga bersifat individual. Bakat dan 'kekosongan' individu yang seolah bertentangan dikumpulkan oleh Stern sebagai keutuhan pribadi bukan sosial. Pesantren yang memahami manusia sebagai fitrah dan prenatal, dapat berdimensi sosial maupun individual. Fitrah manusia yang berdimensi dunia dan akhirat tergambarkan dalam nilai ketuhanan lain yaitu rahmatan lil âlamîn (Muthohar, 2007: 98).

Dalam konteks keilmuan, pesantren menganggap ilmu agama/ukbrawi wajib dipelajari secara individu (fardhu 'ain) dan bernilai sakral, sedangkan ilmu non agama yang berdimensi kepentingan bersama (sosial) dikategorikan sebagai ilmu fardhu kifâyah dan tidak dipandang sakral. Ilmu ukhrawi bersumber dari "kitab kuning" yang lebih banyak bermadzhab Syafi'i. Kitab-kitab tersebut meliputi bidang aqidah/tauhid, tajwid (al-Qur'an), akhlak/tasawuf, Bahasa Arab (nahwu, sharaf, balaghah), fiqih, ushul fiqh, tafsir, 'ulùm al-Qur'ân, Hadis, 'ulûm al-hadist dan sejarah Islam. Santri juga dibekali pelajaran tambahan yang dapat menunjang pada ilmu ukhrawi berupa belajar berpidato (muhâdlarah), tahlilan, seni baca alQur'an (naghom) dan berzanji. Pandangan keilmuan pesantren nampak bercorak dualistik, tetapi dalam praktiknya lebih menekankan yang pertama sehingga ia dikategorikan konservatif, memandang kurang penting ilmu-ilmu umum (Muthohar, 2007: 100).

Seiring dengan modernisasi, pesantren mulai membuka sekolah umum (madrasah dan sekolah Islam terpadu) dan melaksanakan kegiatan vocational untuk membekali santri/murid menjalani 'kehidupan dunia'. Pesantren kemudian memasukkan (science) ilmu non agama. Santri/murid mempelajari ilmu pertanian, peternakan dan perbengkelan. Pesantren modern (kategori 5), karena sudah mengadopsi sistem pendidikan formal (madrasah dan/atau sekolah), maka pada dasarnya menggunakan kurikulum perpaduan antara kurikulum pesantren dengan Departemen Agama dan Departemen Pendidikan dan Kebudayaan (Nasional). Selain santri belajar 'kitab kuning' dengan pola pesantren, juga belajar secara klasikal (di bagi ke dalam sejumlah kelas). Pemaduan kurikulum dijalankan secara bervariasi. Ada pesantren menerapkan $100 \%$ kurikulum umum dan 100 $\%$ kurikulum pesantren. Di pagi hari santri belajar di madrasah/sekolah, sedangkan pada sore dan malam hari mengikuti pengajian atau Madrasah Diniyah yang khusus mengajarkan 'kitab kuning'. Pesantren lainnya menggabungkan kurikulum lokal (kepesantrenan) 70\% dan kurikulum nasional 30\%. Ada pesantren modern (kategori 5) yang mempunyai kurikulum tersendiri. Ia sama sekali tidak mengadopsi kurikulum nasional, tetapi lulusannya diakui pemerintah bahkan oleh dunia internasional. Contoh untuk ini adalah Pesantren Modern Darussalam Gontor (Zarkasyi, 2005: 2).

Beragamnya kurikulum yang dianut oleh pesantren mengakibatkan telaah kurikulum tidak cukup jika menggunakan konsep kurikulum yang bersifat formal yakni bahan ajar yang sudah tersusun dan ditetapkan oleh lembaga. Kurikulum pesantren tidak hanya meliputi bahan pelajaran tetapi seluruh kehidupan pesantren bahkan secara sinergis melibatkan pertanggungjawaban secara 
langsung terhadap masyarakat sehingga mampu menerangi semua orang (Analisis berdasarkan Ragan dalam Nasution, 1999: 103., Asy-Syaebany, 1979: 478., Ramayulis, 2001: 61., dan Muhaimin, 2010: 1).

Ada pergeseran ideologi kurikulum pesantren dari konservatif ke liberal, namun tetap berciri religius. Sinergi antara konteks 'kehidupan dunia' dengan akhirat (al-dunyâ marra'at al-âkhirah) menunjukkan bahwa pesantren berdimensi ideologi sosial, liberal dan religius. Pesantren tetap bercorak sosial karena ia tidak mengenal sekat ruang dan waktu dalam proses pembelajarannya (24 jam mondok) serta bersatu padu dengan kehidupan keseharian masyarakat. Siang dan malam, santri belajar guna menumbuhkan keefektifan personal yang berdialektika dengan kehidupan masyarakat sekitarnya. Oleh karena itu, pesantren memiliki tiga fungsi sekaligus yaitu sebagai lembaga pendidikan, sosial dan dakwah Islam (penyiaran agama) (Ghazali, 1996: 36-39).

Ciri pesantren sebagai lembaga sosial sangat erat hubungannya dengan upaya pemenuhan tuntutan kehidupan masyarakat, misalnya dalam bimbingan dan konseling keagamaan. Dalam konteks ini, pesantren dianggap bercorak liberasionisme. Pesantren berperan membantu santri/siswa dalam menyiapkan dirinya mengubah tatanan sosial yang mapan (Muthohar, 2007: 100-101). Namun sebetulnya lebih dekat dengan sosialisme. Masyarakat harus ditata supaya kesejahteraan semua orang terwujud (Suseno, 2001: 21). Secara internal hal ini dilakoni santri di pesantren. Santri dibiasakan makan bersama dengan lauk pauk yang sama. Jika ada santri yang enggan berbaur maka santri tersebut dengan sendirinya di/terkucilkan.

Pesantren salafiyah (termasuk kategori 1, 2 dan 3) dalam pembelajarannya lebih mengutamakn penggunaan metode sorogan, wetonan/bandongan, halaqah, tahfį̌h, bahtsul masail, biwâr, fatbul kutub dan muqâranah. Halaqah adalah metode belajar berkelompok untuk membahas atau mendiskusikan suatu topik yang merupakan isi dalam salah satu kitab. Metode ini bertujuan untuk mengembangkan intelektual santri dalam memahami isi kitab. Metode ini cukup efektif dan dinamis karena terjadi dialog di antara santri. Biasanya santri senior memimpin pembelajaran sedangkan kiai atau ustadz hanya memantau jalannya diskusi. Metode halaqah hampir sama dengan metode biwâr dan bathsul masâil. Metode biwâr lebih untuk pengayaan atau memperdalam materi yang sudah dikaji sedangkan metode bathsul masail, membahas topik yang didiskusikan secara lebih luas dan tidak terbatas pada satu kitab. Metode babtsul masail dibantu dengan metode fatbul kutub, di mana para santri diberi tugas untuk mencari rujukan dalam beberapa kitab terhadap suatu masalah. Kedua metode tersebut kemudian dilengkapi dengan metode muqâranah, yakni santri diberi tugas untuk membandingkan pendapat beberapa madzhab yang terdapat dalam berbagai kitab (Abdul Fatah, 2005: 67-62).

Secara ideologis, metode hafalan, ceramah dan bandongan merupakan ciri khas fundamentalisme, intelektualisme dan konservatisme yang mempunyai kecenderungan ke arah mempertahankan tata cara dalam kelas di bawah 
pengawasan guru yang terstruktur dengan ketat. Ideologi tersebut cenderung menyukai disiplin dan hafalan sebagai cara memapankan kebiasaan yang layak pada tingkat pendidikan rendah. Mereka cenderung memilih metode 'luar kepala' dengan mengutamakan jawaban yang persis seperti yang diajarkan gurunya. Metode bandongan cenderung sejalan dengan ideologi intelektualisme, karena di dalamnya mengarah kepada pendekatan intelektualisme yang terbuka pada penalaran formal. Perangkat umum metode ini adalah ilmu logika (manthiq). Metode halaqah dapat dipandang mencerminkan ideologi konservatisme, karena cenderung menempatkan siswa yang berintelektual tinggi dapat mempengaruhi siswa lain. Senioritas intelektual mewarnai secara kuat dalam metode ini. Namun di sisi lain, halaqah mencerminkan kebersamaan (sosialis), semua santri, termasuk kiai dapat berdiskusi terutama saat membandingkan satu kitab dengan kitab lain (muqâranab). Kenyataannya, kultur pesantren belum bisa menempatkan secara sejajar antara kiai, santri senior dan santri pada umumnya. Namun secara ideologis, halaqah dan sejenisnya sejalan dengan prinsip liberal (menghargai kemampuan individu) dan sosial (kebersamaan). Kini, pesantren pun menggunakan metode dan pendekatan lain, yang dianggap lebih ilmiah. Mereka meneliti, bereksperimen dan mengobservasi terhadap berbagai gejala alam (penentuan hilâl dan ru'yat) dan sosial (berpolitik/ berpartai). Dalam arti ini, pesantren memiliki banyak muatan ideologi, baik liberal, sosial, konservatif, maupun religius (Muthohar, 2007: 103).

Evaluasi pembelajaran di pesantren, diukur dari kemampuan mengajarkan kitab kepada orang lain. Jika dalam perspektif mustami' 'memuaskan' dan mendapat 'restu' kiai, berarti santri tersebut lulus. Restu kiai menjadi kunci evaluasi, oleh karena itu evaluasi pembelajaran di pesantren umumnya konservatif. Dalam ideologi konservatif, penilaian cenderung mengutamakan penguasaan informasi tertentu dibanding dengan tes yang menekankan pada analisis, berarti metode evaluasi tersebut pun dapat dikatakan bermuatan ideologi intelektualisme. Akan tetapi, restu kiai sebagai pelegitimasi individual, pada saat yang bersamaan berhadapan dengan mustami, jamaah, orang lain (the other) yang juga berhak menentukan berkualitas-tidaknya calon lulusan pesantren. Dalam arti liberal, masyarakat luas bisa sangat dominan dalam menentukan tingkat kualifikasi seorang santri atau kiai. Boleh jadi, santri tersebut pintar dalam menguasai sejumlah materi agama namun karena dalam penyampaiannya kurang dapat diterima oleh masyarakat, maka masyarakat kurang antusias mengikuti pengajiannya. Dalam hal ini kiai lebih berperan melegitimasi konten sementara masyarakat berperan dalam penilaian metodologis. Ada keterarahan antara santri, kiai dan mustami/masyarakat. Berarti sistem evaluasi pembelajaran pesantren mencerminkan sisi ideologis sosial, liberal dan konvensional.

Sistem organis dan anorganis pesantren pada dasarnya dapat diringkas ke dalam beberapa prinsip pendidikan pesantren, yaitu; 1) teosentris, 2) sukarela dan mengabdi, 3) kearifan, 4) kesederhanaan, 5) kolektivitas, 6) mengatur kegiatan bersama, 7) kebebasan terpimpin, 8) mandiri, 9) mengamalkan ajaran Islam, 10) 
mencari ilmu, 11) tanpa ijazah dan 12) restu kiai. Ketika semua aspek sistemis dan prinsipal dari pesantren ditelaah dalam konteks ideologi pendidikan O'neil, maka secara simultan, pesantren mengandung baik paham konservatif (fundamentalisme dan intelektualisme) maupun liberal (liberasionisme dan mungkin anarkisme-karena anti ijazah) pendidikan. Namun ada satu yang luput dari ideologi O'neil yaitu sosialisme. Dalam liberasionisme, O'neil telah menyiratkan aspek sosial dan kemasyarakatan tetapi tidak menyebut sama sekali sosialisme. Hal ini dapat dipahami karena ia terlalu kuat berada dalam posisi liberalisme, sebagaimana lazimnya para intelektual Amerika dalam menguraikan pandangan akademiknya. Telaah ideologi pesantren yang terlalu berpegang padanya akan mengeliminasi sejumlah nilai yang berdimensi ideologi sosial.

Saat pesantren berprinsip bahwa santri harus diperlakukan secara kolektif (sama rasa-sama rata), tidak ada beda antara anak pejabat dan jelata, lalu ada kesatupaduan antara kegiatan belajar santri dengan kehidupan sehari-hari masyarakat maka ia tidak hanya dipahami sebagai liberasionisme, namun lebih jujur jika dimaknai sebagai sosialisme. Secara teologis misi penekanan pada kebermanfaatan bagi masyarakat menunjukkan bahwa pesantren memiliki ideologi sosialis-kerakyatan (QS. Al-Baqarah [2]: 83). Penekanan pada pembentukan perilaku sosial yang lebih efektif dan maju (al-muhâfadzatu 'ala alqadìm as-shalih wa al-akhdzu bi al-jadîd al-ashlah) dan menempatkan manusia sebagai fitrah dan prenatal, selalu berdimensi sosial sekaligus religius. Siang dan malam, santri belajar menumbuhkan keefektifan personal yang berdialektika dengan kehidupan masyarakat tercermin dalam metode halaqah yang berpotensi mengajarkan kebersamaan (sosialis).

\section{SIMPULAN}

Ideologi dasar pesantren bersumber dari ajaran Islam namun kecenderungan pesantren yang selalu berupaya menyesuaikan diri dengan zaman (madrasah dan sekolah) menyebabkan ahli pendidikan Islam mengklasifikasikan pesantren ke dalam lima kategori, yaitu; 1) pesantren yang secara fisik hanya memiliki masjid dan rumah kiai, metode yang bandongan dan sorogan; 2) pesantren yang terdiri atas masjid, rumah kiai dan asrama dengan metode tambahan resitasi; 3) pesantren yang berfasilitas sama dengan nomor dua dan ia menyelenggarakan pendidikan formal /madrasah; 3) pesantren yang telah memiliki ciri nomor tiga dan menyelenggarakan pendidikan keterampilan (peternakan, kerajinan rakyat, koperasi dan pertanian); 5) pesantren modern yang berfasilitas lengkap (perpustakaan, dapur umum, ruang tamu, ruang makan, kantor administrasi, toko dan koperasi, gedung pertemuan, kamar mandi, WC dan labolatorium) dan memadai. Pesantren model/kategori ini menyelenggarakan; pengajian kitab klasik/kuning, pembelajaran sejumlah materi yang lazim diberikan di madrasah dan/atau sekolah umum dari tingkat dasar hingga pendidikan tinggi, ditambah dengan materi pendidikan vokasional/keterampilan dan program pengembangan lingkungan. Beragamnya jenis dan kategori pesantren mengandaikan adanya 
keragaman nilai, budaya dan ideologi yang dianut oleh pesantren. Ia bisa berideologi konservatif (fundamentalisme, intelektualisme) dan liberal (liberasionisme dan anarkisme) (O'neil, 2002) bahkan sosial-liberal (religius). Berdasarkan telaah liberasionisme O'neil, tersirat aspek sosial dan kemasyarakatan pesantren tetapi ia tidak (mungkin) menyebut sebagai sosialisme, karena sudut pandangnya terlalu liberal. Telaah yang lebih objektif dapat menunjukkan bahwa pesantren memiliki sejumlah nilai yang berdimensi ideologi sosial, yaitu pada saat pesantren; 1) berprinsip bahwa santri harus diperlakukan secara kolektif (sama rasa-sama rata) yakni tidak ada perlakuan khusus pada santri tertentu; 2) berpegan teguh pada prinsip kesatupaduan antara kegiatan belajar santri dengan kehidupan sehari-hari masyarakat; 3) dilandasi oleh sejumlah ajaran teologis yang menuntut kebermanfaatan bagi masyarakat (QS. Al-Baqarah [2]: 83); 4) bertujuan membentuk perilaku sosial santri yang lebih efektif dan maju; 5) menempatkan manusia secara fitrah dan prenatal sehingga sepanjang siang dan malam, santri belajar secara terus-menerus (di pondok dan di masyarakat); 6) menafsirkan ulang metode halaqah yang berpotensi mengajarkan kebersamaan (sosialis).

\section{DAFTAR PUSTAKA}

Abdul Fatah, Rohandi, dkk. 2005. Rekontruksi Pesantren Masa Depan, Jakarta: Listafariska Putra.

Al-Syaebany, Omar Muhammad Al-Toumy. 1979. Falsafat at-Tarbiyyah alIslâmiyyah, terjemahan Hasan Langgulung: Filsafat Pendidikan Islam, Jakarta: Bulan Bintang.

Ali, Lukman. 1994. Kamus Besar Bahasa Indonesia, Edisi II. Jakarta: Departemen P \& K Republik Indonesia, Balai Pustaka.

Arifin, M. 1991. Kapita Selekta Pendidiken Islam dan Umum. Jakarta: Bumi Aksara

Ghazali, M. Bahri. 1996. Pesantren Berwawasan Lingkungan. Jakarta: CV. Prasasti.

Illich, Ivan. 1982. Bebas dari Sekolah. Jakarta: Yayasan Obor.

Mastuhu. 1994. Dinamika Sistem Pendidikan Pesantren Suatu Kajian Tentang Unsur dan Nilai Sistem Pendidikan Pesantren, Jakarta: INIS.

Madjid, Nurcholis. 1997. Bilik-bilik Pesantren: Sebuab Potret Perjalanan. Jakarta: Paramadina.

Saridjo, Marwan. 1979. Sejarah Pondok Pesantren di Indonesia. Jakarta: Dharma Bakti.

Muthohar, Ahmad. 2007. Ideologi Pendidikan Pesantren: Pesantren di Tengah Arus Ideologi-Ideologi Pendidikan. Semarang: Pustaka Rizki Putra.

Nasution, S. 2003. Asas-Asas Kurkulum. Jakarta: Bumi Aksara.

Nasution, S. 2010. Pengembangan Kurikulum Pendidikan Agama Islam di Sekolah, Madrasah dan Perguruan Tinggi. Jakarta: Raja Grafindo Persada.

O’neil, William F. 2001. Ideologi-ideologi Pendidikan. Yogyakarta: Pustaka Pelajar.

Peraturan Pemerintah RI nomor 19 Tahun 2005 tentang Standar Nasional Pendidikan. 
Raharjo, M. Dawam. 1985. Pergulatan Dunia Pesantren Membangun dari Bawah, Jakarta: P3M.

Ramayulis. 2010. Ilmu Pendidikan Islam. Jakarta: Kalam Mulia.

Sumpeno, Ahmad dkk., 2002. Pembelajaran Pesantren Suatu Kajian Komparatif.

Jakarta: Departemen Agama dan INCIS.

Suryanto dan Djihad Hasyim. 2000. Refleksi dan Reformasi Pendidikan di Indonesia Memasuki Milenium III. Jakarta: Adicita.

Suseno, Frans Magnis. 2000. Pemikiran Karl Marx. Jakarta: Gramedia.

Syukri Zarkasyi, Abdullah. 2005. Manajemen Pesantren Pondok Pesantren Modern. Ponorogo: Trimurti Press.

Undang-undang RI Nomor 20 Tahun 2003 tentang Sistem Pendidikan Nasional. Zarkasyi, Imam. 1973. Beberapa Pokok Pikiran Tentang Pondok Pesantren. Ponorogo: Trimurti Press. 